\title{
Selection and characterization of scFv antibody against nucleocapsid protein of Porcine reproductive and respiratory syndrome virus
}

\author{
Magdalena Krasna ${ }^{1,2}$, Vladimir Celer ${ }^{1,2}$ \\ University of Veterinary and Pharmaceutical Sciences Brno, ${ }^{1}$ Faculty of Veterinary Medicine, Institute of Infectious \\ Diseases and Microbiology, ${ }^{2}$ CEITEC - Central European Institute of Technology, Brno, Czech Republic
}

Received January 21, 2019

Accepted February 25, 2020

\begin{abstract}
Porcine reproductive and respiratory syndrome virus (PRRSV) is a widespread infectious agent in pigs. Nucleocapsid (N) protein of PRRSV has been identified as the most immunodominant viral protein. The main goal of the work was the selection and characterization of a singlechain antibody fragments ( $\mathrm{scFv}$ ) antibody specific to the $\mathrm{N}$ protein. Specific $\mathrm{scFv}$ antibody clone D5 was selected from the Tomlinson phagemid library and purified by immobilized metal affinity chromatography from the periplasmatic space of $E$. coli cells. The antibody was then characterized by sequencing and the ability to recognize the native virus $\mathrm{N}$ protein by Western blot and competitive ELISA. Pepscan analysis identified the position of the binding epitope between amino acids $62-84$ of the N protein. Our study could help to improve the diagnostics and prevention of PRRSV in Central Europe.
\end{abstract}

N protein, expression, binding epitope, immunoblot, ELISA

Porcine reproductive and respiratory syndrome (PRRS) is characterized by reproductive failure in sows, respiratory distress in piglets and growing pigs. The causative agent of PRRS is an enveloped, positive-stranded RNA virus classified to the genus Porartevirus, family Arterivividae in the order Nidovirales. Two previously recognized genotypes were recently classified as independent virus species. Former European virus genotype (Genotype I) is now designated as Porcine reproductive and respiratory syndrome virus 1 (Adams et al. 2017). The viral genomic RNA is coding nine open reading frames (ORFs): ORF1 ( $1 \mathrm{a}-1 \mathrm{~b}$, encoding a replicase polyprotein), and ORF 2 to 7 (encoding six structural proteins). Minor membrane-associated glycoproteins (GP2, GP3, and GP4) are the products of ORFs 2 to 4. Open reading frames 5 to 7 are coding major structural proteins - GP5, M, and N proteins (Meulenberg et al. 1997; Ostrowski et al. 2002; Johnson et al. 2011). The nucleocapsid N protein (ORF7) of the virus is a small basic protein with molecular mass of $15 \mathrm{kDa}$. The expression is localized in the nucleus (Rowland et al. 1999) of infected cells and represents 20-40\% of the protein content of the virion (de Vries et al. 1992; Faaberg and Plagemann 1995; Godeny et al. 1995; Bautista et al. 1996). The $\mathrm{N}$ specific antibodies are produced within the first few days following infection and represent a vast majority of the total antibody response against the virus (Urniza et al. 1997). For these reasons, N protein is the main antigen in currently used serological tests (Meulenberg et al. 1995; Cho et al. 1996; Denac et al. 1997; Seuberlich et al. 2002; Ferrin et al. 2004). Monoclonal antibodies (mAbs) are useful components of diagnostic tests ensuring adequate sensitivity and particularly their specificity (Yoon et al. 1995; Dea et al. 2000; Ren et al. 2010; Van Breedam et al. 2011). However, the development of reliable mAbs is labour-intensive and timeconsuming. Protein engineering has made it possible to manipulate recombinant antibodies and to construct antibodies which retain complete antigen binding function (Muller et

Address for correspondence:

Mgr. Magdalena Krasna

Institute of Infectious Diseases and Microbiology

University of Veterinary and Pharmaceutical Sciences Brno

Palackého tř. 1946/1, 61242 Brno, Czech Republic

Phone: +420541562280

E-mail: magdalena.krasna@yahoo.com

http://actavet.vfu.cz/ 
al. 1997). Single-chain antibody fragments ( $\mathrm{scFv}$ ) consist of variable regions of heavy and light chains with a connecting flexible linker (Bird et al. 1988). In contrast to the natural antibody secreted to an extracellular environment, $\mathrm{scFv}$ can be easily expressed in a functional form in Escherichia coli, allowing protein engineering to improve the properties of $\mathrm{scFv}$ such as the increase of affinity and alternation of specificity (Munro and Pelham 1987; Bird et al. 1988).

The aim of this study was the selection and characterization of recombinant $\mathrm{scFv}$ antibodies directed against the $\mathrm{N}$ protein of the PRRS virus which could later be used in the development of diagnostic methods or possibly in studies of the life cycle of the virus.

\section{Materials and Methods}

Expression of recombinant $\mathrm{N}$ protein

Expression and purification of recombinant $\mathrm{N}$ protein of PRRS 1 virus was performed according to a previously published procedure (Janková and Celer 2012). The appropriate virus gene was PCR amplified and cloned into pENTR-TM/SD/D-TOPO ${ }^{\circledR}$ Vector (Invitrogen. Thermo Fisher Scientific, Waltham, USA) and subsequently subcloned into pDestTM17 Gateway ${ }^{\circledR}$ Vector (Invitrogen) by site-specific recombination. The expression of recombinant protein was performed in BL21 (DE3) pLysS E. coli strain (Stratagen, La Jilla CA). The resulting recombinant $\mathrm{N}$ protein was purified by immobilized-metal affinity chromatography (IMAC) using a polyhistidine tag under denaturing conditions using a NGC Chromatography System (Bio-Rad, Hercules, California, USA).

\section{Selection of $\mathrm{N}$ specific recombinant phages}

Human Tomlinson $\mathrm{I}+\mathrm{J}$ scFv phage library (Laboratory of Molecular Medicine, MRC, Cambridge) was used. The library is in a phagemid format that allows scFv to be expressed either on the surface of a bacteriophage, or in an alternative E. coli producing a soluble scFv. The diversity of libraries (I and J) is estimated to $1.47 \times 10^{8}$ for I and $1.37 \times 10^{8}$ for $\mathrm{J}$. The soluble $\mathrm{scFv}$ fragments produced bear c-myc and poly-histidine tags to facilitate detection and purification. The panning procedure and the selection of monoclonal scFv antibodies was already described (Celer et al. 2003) with minor modifications.

The immunotube (NUNC, ThermoFisher Scientific, Waltham, USA) was coated with $100 \mu \mathrm{g} / \mathrm{ml}$ of recombinant $\mathrm{N}$ protein (PRRSV1) overnight at $4{ }^{\circ} \mathrm{C}$. After blocking with $2 \%$ skimmed milk, $10^{12}$ recombinant phages were added and incubated for $2 \mathrm{~h}$ at room temperature (RT). After washing with phosphate buffered saline (PBS) containing $0.1 \%$ Tween 20 , bound phages were eluted by $100 \mathrm{mM}$ trietylamine and immediately neutralized with $1 \mathrm{M}$ Tris $\mathrm{pH}$ 7.4. Exponentially growing TG1 E. coli cells (MRC, Cambridge, UK) were then used to amplify eluted phages. TG1 cells were infected with $250 \mu \mathrm{l}$ of eluted phages for $30 \mathrm{~min}$ at $37^{\circ} \mathrm{C}$ without shaking. Fifty $\mu 1$ of infected cells were plated on tryptone yeast extract (TYE) agars supplemented with $100 \mu \mathrm{g} / \mathrm{ml}$ ampicillin and $1 \%$ glucose and incubated overnight at $37^{\circ} \mathrm{C}$. The TYE medium was added $(1-2 \mathrm{ml})$ to the cells grown on the plate. Fifty $\mu \mathrm{l}$ of loosened cells were resuspended in the $50 \mathrm{ml}$ TYE medium containing $100 \mu \mathrm{g} / \mathrm{ml}$ ampicillin, $1 \%$ glucose and were shaken until $\mathrm{OD}_{600}$ reached 0.4 (spectrophotometer: SmartSpec 3000, Bio Rad, CA, USA). Ten $\mathrm{ml}$ of grown bacteria were infected with helper phage KM13 (MRC, Cambridge, UK) (at a final concentration of $5 \times 10^{10}$ ) and were left for $30 \mathrm{~min}$ at $37^{\circ} \mathrm{C}$ without shaking and then spun at 3,300 $\mathrm{g}$ for $10 \mathrm{~min}$. The bacterial pellet was resuspended in $50 \mathrm{ml}$ of TYE medium containing $100 \mu \mathrm{g} / \mathrm{ml}$ ampicillin, $25 \mu \mathrm{g} / \mathrm{ml} \mathrm{kanamycin} \mathrm{and}$ $1 \%$ glucose and grown overnight at $30{ }^{\circ} \mathrm{C}$. The night culture $(40 \mathrm{ml})$ was spun at $10,800 \mathrm{~g}$ for $30 \mathrm{~min}$ and the supernatant was used in precipitation of $\mathrm{scFv}$ phage with $8 \mathrm{ml} 20 \%$ polyethylene glycol $6000,2.5 \mathrm{M} \mathrm{NaCl}(\mathrm{PEG} /$ $\mathrm{NaCl}$ ) for $1 \mathrm{~h}$ at $4{ }^{\circ} \mathrm{C}$. The mixture was centrifuged at $3,300 \mathrm{~g}$ for $30 \mathrm{~min}$ and the pellet containing the scFv phage was resuspended in $2 \mathrm{ml}$ of PBS. The $\mathrm{scFv}$ phage obtained was used for the next round of selection. In total, five rounds of panning were carried out.

\section{Production of soluble scFv antibodies}

Selected recombinant phages were used to infect HB2151 E. coli cells (MRC, Cambridge, UK). Exponentially grown HB2151 cells $\left(\mathrm{OD}_{600}=0.4\right)$ were infected by selected $\mathrm{N}$ specific phages for $30 \mathrm{~min}$ at $37^{\circ} \mathrm{C}$. Then the mixture was spotted on TYE agar supplemented with $100 \mu \mathrm{g} / \mathrm{ml}$ ampicillin, $1 \%$ glucose and incubated overnight at $37^{\circ} \mathrm{C}$. Individual colonies were inoculated in $2 \times$ tryptone yeast (TY) medium supplemented with $100 \mu \mathrm{g} / \mathrm{ml}$ ampicillin and $0.1 \%$ glucose and expression of recombinant antibodies was induced by $1 \mathrm{mM}$ IPTG (isopropyl $\beta$-D-thiogalactoside). Production of soluble N specific scFvs was tested by ELISA (Crow ther 2009).

Soluble monoclonal $\mathrm{scFv}$ antibodies were purified from the periplasmatic space by osmotic shock. The bacterial pellet was lysed in sucrose buffer $(\mathrm{pH}=7.5)(200 \mathrm{mM}$ Tris $\mathrm{HCl}, 20 \%$ sucrose, $1 \mathrm{mM}$ EDTA) for $10 \mathrm{~min}$ at RT, then chilled milliQ water was added for additional $5 \mathrm{~min}$. Cell debris was removed by centrifugation at $8,000 \mathrm{~g}$ for $30 \mathrm{~min}$ and the supernatant was dialyzed at $4{ }^{\circ} \mathrm{C}$ for $16 \mathrm{~h}$ to remove EDTA. Then $0.1 \mathrm{M}$ DTT and benzonase were added and incubated for $1 \mathrm{~h}$ at RT. Recombinant $\mathrm{scFv}$ was purified by IMAC using a polyhistidine tag using the NGC Chromatography System (Bio-Rad, Hercules, USA). 


\section{Sequencing}

Positive phagemid clones were characterized by sequencing. Phagemid DNA was extracted and heavy chain variable $(\mathrm{VH})$ and light chain variable (VL) region was PCR amplified using vector specific primers, gel purified amplicons were sequenced (Macrogen Europe, Amsterdam, The Netherlands). The sequences obtained were analysed by Nucleotide BLAST (https://blast.ncbi.nlm.nih.gov/Blast.cgi) to identify the complementarity determining regions (CDRs) in heavy chain (VH) and light chain (VL) variable region. Multiple sequence alignment was performed using Geneious v.10 software (Biomatters Ltd, Auckland, New Zealand).

\section{Competitive ELISA}

To analyse the specificity of the scFv antibody to PRRS $\mathrm{N}$ protein, competitive ELISA was performed. The 96 well flexible assay plate was coated with $100 \mathrm{mg} / \mathrm{ml}$ of the recombinant $\mathrm{N}$ protein overnight at $4{ }^{\circ} \mathrm{C}$. Porcine sera (PRRS specific antibodies determined by IDEXX ELISA (Idexx Laboratories, Inc., Maine, US) were diluted 1:100 (determined by checkerboard titration). After blocking with $2 \%$ bovine serum albumin (BSA, Sigma Aldrich, Darmstadt, Germany) $50 \mu \mathrm{l}$ of 1:1, the mixture containing swine serum and our scFv antibody (D5) (diluted 1:100) was added and incubated at RT for $1 \mathrm{~h}$. After washing with T-PBS (PBS, 0.1\% Tween 20), $100 \mu \mathrm{l}$ of anti-c-myc-peroxidase (Merck, Darmstadt, Germany) diluted 1:30 000 (2\% BSA in PBS) were added and incubated for $1 \mathrm{~h}$ at RT. Plates were then washed three times with T-PBS and the reaction was developed using 3,3'5,5'-tetramethylbenzidine (Test-Line, Brno, Czech Republic). Colour development was stopped with $1 \mathrm{~N} \mathrm{H}_{2} \mathrm{SO}_{4}$ and the optical density was read at $450 \mathrm{~nm}$ (Infinite M200 PRO, Tecan, Austria).

\section{Identification of antibody binding site}

To identify the position of D5 binding epitope, N protein was synthesized as six aa20-mers (Genecust, Ellange, Luxembourg) (Table 1). The binding site was then identified by peptide ELISA. Ten wells of a 96-well plate were coated overnight with $5 \mathrm{ng}$ per well of each of the peptides diluted in carbonate buffer $(\mathrm{pH} 7.4)$ at $4{ }^{\circ} \mathrm{C}$. The plate

Table 1. Sequence and position of peptides covering the whole length of the $\mathrm{N}$ virus protein. The amino acid sequence and position in the $\mathrm{N}$ protein is indicated.

\begin{tabular}{llc}
\hline Peptide & aa sequence & Position \\
\hline Peptide 1 & MAGKNQSQKKKKSTAPMGNG & $1-20$ \\
Peptide 2 & QPVNQLCQLLGAMIKSQRQQ & $21-40$ \\
Peptide 3 & PRGGQAKKKKPEKPHFPLAAED & $41-61$ \\
Peptide 4 & DIRHHLTQTERSLCLQSIQTAF & $62-84$ \\
Peptide 5 & NQGAGTASLSSSGKVSFQVEFM & $85-107$ \\
Peptide 6 & LPVAHTVRLIRVTSTSASQGAS & $108-130$ \\
\hline
\end{tabular}
was then blocked by $2 \%$ BSA in PBS, and $50 \mu 1$ of D5 antibody clone $(1: 100)$ were added to the wells and incubated for $1 \mathrm{~h}$ at RT. Irrelevant $\mathrm{scFv}$ antibody served as a negative control. After washing with T-PBS, $100 \mu \mathrm{l}$ of anti-c-myc-peroxidase (diluted 1:5000 in PBS with 2\% BSA) were added and incubated for $1 \mathrm{~h}$ at RT. After washing, the reaction was developed using 3,3' 5, 5' -tetramethylbenzidine (TestLine, Brno, Czech Republic). Colour development was stopped with $1 \mathrm{~N} \mathrm{H}_{2} \mathrm{SO}_{4}$ and the optical density was read at $450 \mathrm{~nm}^{2}$ (Infinite M200 PRO, Tecan, Austria).

\section{Results}

\section{Selection of $\mathrm{scF} v$ antibodies}

Five rounds of $\mathrm{scFv}$ antibodies selection were performed. After each selection round, a titre of the eluted phages was determined to evaluate the efficiency of selection (Plate VI, Fig. 1). The number of selected binders increased approximately $100 \times$ between the first and fourth selection rounds. The increasing number of $\mathrm{N}$ specific binders in the total phage population was confirmed by polyclonal scFv-phage ELISA performed after each selection round (data not shown). To identify individual binders, $\mathrm{scFv}$ phages eluted in the third and fourth selection rounds were used to infect TG1 E. coli. Randomly selected colonies were tested for their ability to bind PRRS N protein in ELISA test and immunoblot. In total, fourth clones were identified as N protein specific binders (Plate VI, Fig. 2).

\section{Production of soluble scFv antibodies}

The specific binders identified were then used to infect nonsuppressor strain $E$. coli HB2151 and tested for the expression of soluble scFv molecules. Only two clones were able to express whole length soluble scFv molecules. For further analysis, these two clones (labelled as B4 and D5) were expressed and purified from bacterial periplasm by IMAC. The expression level of the B4 clone was substantially lower than that of D5. For this 
reason, further experiments were performed with the D5 clone only. The yield of purified soluble form of D5 scFv reached $1 \mathrm{mg}$ per 1 litre of bacterial suspension. The soluble D5, containing polyhistidine tag, was purified from bacterial periplasm by osmotic shock and the purity of the scFv obtained was checked on 12\% SDS-PAGE gel (Plate VII, Fig. 3).

\section{Sequencing}

For further characterization, both clones (B4 and D5) were sequenced. The VH and VL regions, polyhistidine tag and the linker are shown and compared in Fig. 4 (Plate VII).

\section{Identification of the D5 binding site}

To identify the binding epitope of D5 scFv antibody, $\mathrm{N}$ protein was synthesized as six independent peptide fragments. The reactivity of D5 scFv clone with individual peptides in ELISA test is shown in Fig. 5 (Plate VIII). The D5 scFv displayed the strongest reactivity with peptide 4 spanning aa $62-a a 84$.

\section{Competitive ELISA}

The specificity of soluble D5 $\mathrm{scFv}$ to $\mathrm{N}$ protein was estimated by competitive ELISA test on the panel of PRRS positive and negative swine sera. The dilution of swine sera and $\mathrm{scFv}$ antibody was determined by checkerboard titration. The result of swine sera testing is shown in Fig. 6 (Plate VIII). The PRRS positive sera (sera 1-10) gave significantly different reactivity compared to negative sera (11-20).

\section{Discussion}

Porcine reproductive and respiratory syndrome virus is one of the most important viral pathogens affecting the swine industry. The development of new sensitive and specific diagnostic tests is therefore crucial to prevent the spread of the virus among host animals and for the introduction of successful control programs. Monoclonal antibodies (mAbs) are useful components of diagnostic tests ensuring adequate sensitivity and particularly their specificity (Yoon et al 1995; Dea et al 2000; Ren et al 2010; Van Breedam et al 2011). However, the development of reliable mAbs is labour-intensive and time-consuming, and the binding affinity of mAbs can easily be affected by amino acid changes in the target structure. This drawback can partially be overcome by $\mathrm{scFv}$ antibodies which can be selected from a scFv library and following characterization can easily be produced and purified in an E. coli expression system in large quantities. The whole procedure is fast and can be achieved in several weeks (Nieba et al 1997; Klimka et al 2000; Watkins and Ouwehand 2000).

The goal of our work was the development of a soluble scFv antibody against $\mathrm{N}$ protein PRRSV which could be used in the development of improved diagnostic methods, and for studying the role of $\mathrm{N}$ protein in the virus life cycle. Recombinant virus $\mathrm{N}$ protein has already been developed in our laboratory (Janková and Celer 2012) and used as antigen for $\mathrm{scFv}$ selection.

The Tomlinson semi-synthetic libraries were chosen for recombinant phage selection. Selection revealed a pattern of phage recovery that was consistent with the progressive enrichment of target-specific clones. In percentage terms, recoveries rose steadily from round 1 to round 4 . Since recovery data provide only a preliminary indication of the progress of selection, monoclonal phage ELISA was a critical benchmark for these experiments. This clearly revealed that clones in rounds 3 and 4 showed high reactivity with $\mathrm{N}$ protein. The input of recombinant phage particles used in each round of selection was $10^{12}$. In the fourth round of selection the proportion of $\mathrm{N}$ protein specific phages to the whole phage population was approximately $1: 10^{4.5}$ in comparison with the second round in which this 
proportion was estimated to $1: 10^{6.5}$. The overall enrichment of specific phages was then of one hundred times in four selection rounds. Similar enrichment was also obtained in our previous experiments (Celer et al 2003; Blazek et al. 2004). Finally, two clones labelled as D5 and B4 were chosen for further characterization by sequencing and were expressed as soluble scFv fragments.

In prokaryotic cells, recombinant proteins cannot form disulphide bonds in the reducing environment of the cytoplasm (Pollitt and Zalkin 1983; Derman and Beckwith 1991). On the other hand, the oxidative environment of periplasmatic space in Gram-negative bacteria is suitable for expression of disulphide-bonded proteins (de Marco 2009). The expression of soluble scFv fragments was thus performed from the periplasmatic space of HB2151 E. coli cells. Expression of scFv was checked by picking at random a number of eluted clones and infecting them into E. coli HB2151. The Tomlinson phagemid library is known to contain a high percentage of $\mathrm{scFv}$ clones containing stop codon leading to premature termination of scFv translation (Cárcamo et al 1998; Barderas et al 2006). Supernatants from induced cultures were screened by immunoblot and only those producing full length $\mathrm{scFv}$ molecules were used in further experiments. Normally, conventional $E$. coli strains produce target $\mathrm{scFv}$ in the inactive form due to the reducing environment of the cytoplasm. Expression of scFv molecule in periplasm in the majority of cases leads to the expression of soluble molecule with no need for refolding and easy purification (Yang et al 2010). A large amount of IMAC purified D5 (1 mg) was obtained from 1 litre of culture medium.

The full-length expression was only observed in B4 and B5 clones, but only the D5 clone expressed a sufficient amount of recombinant scFv molecule. The failure to express the B4 clone was most likely due to factors such as stability of variable domains and their folding process, which also influenced affinity to the antigen (Kipriyanov et al 1997; Ewert et al 2003). The primary sequence of particular antibody can to some extent also influence expression of recombinant proteins (Nieba et al 1997).

The affinity constant of selected scFv antibodies can be largely influenced by concentration of the antigen used ( $\mathrm{Li}$ et al 2000). Lower antigen concentration favours antibodies with a higher affinity constant, but these conditions diminish the number of selected clones. In our experiments $100 \mathrm{mg} / \mathrm{ml}$ of recombinant $\mathrm{N}$ protein was used in the first selection round. Selection efficiency achieved in our experiment is shown in Fig. 1.

To evaluate the reactivity of the D5 antibody with native $\mathrm{N}$ virus protein, the procedure for indirect competitive ELISA was applied on a set of porcine sera with known PRRS status. As expected, PRRS positive sera displayed considerably lower absorbance data when compared with PRRS negative sera. This clearly proved that the D5 scFv antibody was competing with a serum antibody directed against the same epitope as scFv antibody did. At the same time competitive ELISA demonstrated that developed D5 scFv could be useful in the development of serological diagnostic tests.

To better characterize the D5 antibody, pepscan analysis was performed. For this purpose, $\mathrm{N}$ protein was synthesized as six peptide fragments. The D5 antibody displayed strong reactivity with the fragment labelled as peptide no. 4 covering amino acids $62-84$. Localization of a discontinuous epitope in the same hydrophilic region, (amino acids 55-66) has already been described (Rodriguez et al 1997). The reactivity of the D5 antibody with denatured antigen as well as with native virus antigen suggests that the D5 antibody recognizes continuous linear epitope.

Our goal was to improve the diagnostics and prevention of PRRSV in Central Europe. This was achieved by selection and characterization of a soluble $\mathrm{scFv}$ which has the potential to simplify the production of specific reagents at a large scale. Competitive ELISA in combination with peptide and indirect ELISA was used as a tool for characterization of epitopes of the $\mathrm{N}$ protein. 


\section{Acknowledgements}

This work was supported by "CEITEC - Central European Institute of Technology" (CZ.1.05/1.1.00/02.0068) from the European Regional Development Fund and the project QJ1510108 funded by National Agency for Agricultural Research (NAZV), Czech Republic.

\section{References}

Adams MJ, Lefkowitz EJ, King AMQ, Harrach B, Harrison RL, Knowles NJ, Kropinski AM, Krupovic M, Kuhn JH, Mushegian AR, Nibert M, Sabanadzovic S, Sanfacon H, Siddell SG, Simmonds P, Varsani A, Zerbini FM, Gorbalenya AE, Davison AJ 2017: Changes to taxonomy and the International Code of Virus Classification and Nomenclature ratified by the International Committee on Taxonomy of Viruses. Arch Virol 162: 2505-2538

Barderas R, Shochat S, Martínez-Torrecuadrada J, Altschuh D, Meloen R, Ignacio Casal J 2006: A fast mutagenesis procedure to recover soluble and functional scFvs containing amber stop codons from synthetic and semisynthetic antibody libraries. J Immunol Methods 312: 182-189

Bautista EM, Meulenberg JJM, Choi CS, Molitor TW 1996: Structural polypeptides of American (VR-2332) strain of porcine reproductive and respiratory syndrome virus. Arch of Virol 141: 1357-1365

Bird RE, Hardman KD, Jacobson JW, Johnson S, Kaufman BM, Lee SM, Lee T, Pope SH, Riordan GS, Whitlow M 1988: Single-chain antigen-binding proteins. Science 242: 423-426

Blazek D, Celer V, Navrátilová I, Skládal P 2004: Generation and characterization of single-chain antibody fragments specific against transmembrane envelope glycoprotein gp46 of maedi-visna virus. J Virol Methods 115: $83-92$

Cárcamo J, Ravera MW, Brissette R, Dedova O, Beasley JR, Alam-Moghé A, Wan C, Blume A, Mandecki W 1998: Unexpected frameshifts from gene to expressed protein in a phage-displayed peptide library. Proc Natl Acad Sci U.S.A. 95: 11146-11151

Celer V, Blažek D, Navrátilová I, Skládal P, Blacklaws B, Bujdoso R 2003: Recombinant single-chain Fv antibodies that recognize the p25 protein of the maedi-visna virus. Folia Microbiol (Praha) 48: 435

Cho HJ, Deregt D, Joo HS 1996: An ELISA for porcine reproductive and respiratory syndrome: Production of antigen of high quality. Can J Vet Res 60: 89-93

Crowether JR 2009: The ELISA Guidebook. Humana Press, Vienna, pp. 43-78

de Marco A 2009: Strategies for successful recombinant expression of disulfide bond-dependent proteins in Escherichia coli. Microb Cell Fact 8: 26

de Vries AAF, Chirnside ED, Horzinek MC, Rottier PJM 1992. Structural proteins of equine arteritis virus. J Virol 66: 6294-6303

Dea S, Gagnon CA, Mardassi H, Pirzadeh B, Rogan D 2000: Current knowledge on the structural proteins of porcine reproductive and respiratory syndrome (PRRS) virus : comparison of the North American and European isolates. Arch Virol 154: 659-688

Denac H, Moser C, Tratschin JD, Hofmann MA 1997: An indirect ELISA for the detection of antibodies against porcine reproductive and respiratory syndrome virus using recombinant nucleocapsid protein as antigen. J Virol Methods 65: 169-181

Derman AI, Beckwith J 1991: Escherichia coli alkaline phosphatase fails to acquire disulfide bonds when retained in the cytoplasm. J Bacteriol 173: 7719-7722

Ewert S, Honegger A, Plückthun A 2003: Structure-based improvement of the biophysical properties of immunoglobulin VH domains with a generalizable approach. Biochemistry 42: 1517-1528

Faaberg LS, Plagemann PGW 1995: The envelope proteins of lactate dehydrogenase-elevating virus and their membrane topography. Virology 212: 512-525

Ferrin NH, Fang, Y, Johnson CR, Murtaugh MP, Polson DD, Gramer ML, Nelson EA 2004: Validation of a Blocking Enzyme-Linked Immunosorbent Assay for Detection of Antibodies against Porcine Reproductive and Respiratory Syndrome Virus. Clin Diagn Lab Immunol 11: 503-514

Godeny EK, Zeng L, Smith SL, Brinton MA 1995: Molecular characterization of the 3' terminus of the simian hemorrhagic fever virus genome. J Virol 69: 2679-2683

Janková J, Celer V 2012. Expression and serological reactivity of Nsp7 protein of PRRS genotype I virus. Res Vet Sci 93: 1537-1542

Johnson CR, Griggs TF, Gnanandarajah J, Murtaugh MP 2011 Novek structural protein in porcine reproductive and respiratory syndrome virus encoded by an alternative ORF5 present in all arteriviruses. J Gen Virol 92: 1107-1116

Kipriyanov SM, Moldenhauer G, Martin AC, Kupriyanova O, Little M 1997: Two amino acid mutations in an anti-human CD3 single chain Fv antibody fragment that affect the yield on bacterial secretion but not the affinity. Protein Eng 10: 445-453

Klimka A, Matthey B, Roovers RC, Barth S, Arends JW, Engert A, Hoogenboom HR 2000: Human anti-CD30 recombinant antibodies by guided phage antibody selection using cell panning. Br J Cancer 83: 252-260

Li Y, Cockburn W, Kilpatrick JB, Whitelam GC 2000: High affinity ScFvs from a single rabbit immunized with multiple haptens. Biochem Biophys Res Commun 268: 398-404 
Meulenberg JJM, Bende RJ, Pol JM, Wensvoort G, Moormann RJM 1995: Nucleocapsid protein N of Lelystad virus: expression by recombinant baculovirus, immunological properties, and suitability for detection of serum antibodies. Clin Diagn Lab Immunol 2: 652-656

Meulenber JJM, van Nieuwstadt AP, van Essen-Zanbergen A, Langeveld JP 1997: Posttranslational processing and identification of a neutralization domain of the GP 4 protein encoded by ORF4 of Lelystad virus. J Virol 71: 6061-6067

Muller BH, Lafay F, Demangel C, Perrin P, Tordo N, Flamand A, Lafaye P, Guesdon JL 1997. Phage-display and soluble mouse scFv fragments neutralize rabies virus. J Virol Meth 67: 221-233

Munro S, Pelham HR 1987: A C-terminal signal prevents secretion of luminal ER proteins. Cell 13: 899-907

Nieba L, Honegger A, Krebber C, Pluckthun A 1997: Disrupting the hydrophobic patches at the antibody variable/ constant domain interface: improved in vivo folding and physical characterization of an engineered $\mathrm{scFv}$ fragment. Protein Eng Des Sel 10: 435-444

Ostrowski M, Galeota JA, Jar Am, Platt KB, Osorio FA, Lopez OJ 2002: Identification of neutralizing and nonneutralizing epitopes in the porcine reproductive and respiratory syndrome virus GP5 ectodomain. J Virol 76: $4241-4250$

Pollitt S, Zalkin H 1983: Role of primary structure and disulfide bond formation in beta-lactamase secretion. J Bacteriol 153: 27-32

Ren X, Wang M, Yin J, Li G 2010: Phages harboring specific peptides that recognize the N protein of the porcine reproductive and respiratory syndrome virus distinguish the virus from other viruses. J Clin Microbiol 48: 1875-1881

Rodriguez MJ, Sarraseca J, Garcia J, Sanz A, Plana-Durán J, Ignacio Casal J 1997: Epitope mapping of the nucleocapsid protein of European and North American isolates of porcine reproductive and respiratory syndrome virus. J Gen Virol 78: 2269-2278

Rowland RR, Kervin R, Kuckleburg C, Sperlich A, Benfield DA 1999: The localization of porcine reproductive and respiratory syndrome virus nucleocapsid protein to the nucleolus of infected cells and identification of a potential nucleolar localization signal sequence. Virus Res 64: 1-12

Seuberlich T, Tratschin JD, Thür B, Hofmann MA 2002: Nucleocapsid protein-based enzyme-linked immunosorbent assay for detection and differentiation of antibodies against European and North American porcine reproductive and respiratory syndrome virus. Clin Diagn Lab Immunol 9: 1183-1191

Urniza A, Climent I, Duran JP, Corte's E, Sarraseca J, Casal JI, Vela C 1997: Baculovirus expression of proteins of porcine reproductive and respiratory syndrome virus strain Olot/91. Involvement of ORF3 and ORF5 proteins in protection. Virus Genes 14: 19-29

Van Breedam W, Costers S, Vanhee M, Gagnon CA, Rodríguez-Gómez IM, Geldhof M, Verbeeck M, Van Doorsselaere J, Karniychuk U, Nauwynck HJ 2011: Porcine reproductive and respiratory syndrome virus (PRRSV)-specific mAbs: supporting diagnostics and providing new insights into the antigenic properties of the virus. Vet Immunol Immunopathol 141: 246-257

Watkins NA, Ouwehand WH 2000: Introduction to antibody engineering and phage display. Vox Sang 78: $72-79$

Yang J, Chen R, Wei J, Zhang F, Zhang Y, Jia L, Yan Y, Luo W, Cao Y, Yao L, Sun J, Xu Z, Yang A 2010: Production and characterization of a recombinant single-chain antibody against Hantaan virus envelop glycoprotein. Appl Microbiol Biotechnol 86: 1067-1075

Yoon K, Zimmerman JJ, Mcginley MJ, Landgraf J, Frey ML, Hill HT, Platt KB 1995: Failure to consider the antigenic diversity of porcine reproductive and respiratory syndrome (PRRS) virus isolates may lead to misdianosis. J Vet Invest 7: 386-387 
Plate VI

Krasna M. et al.: Selection and ... pp. 39-45

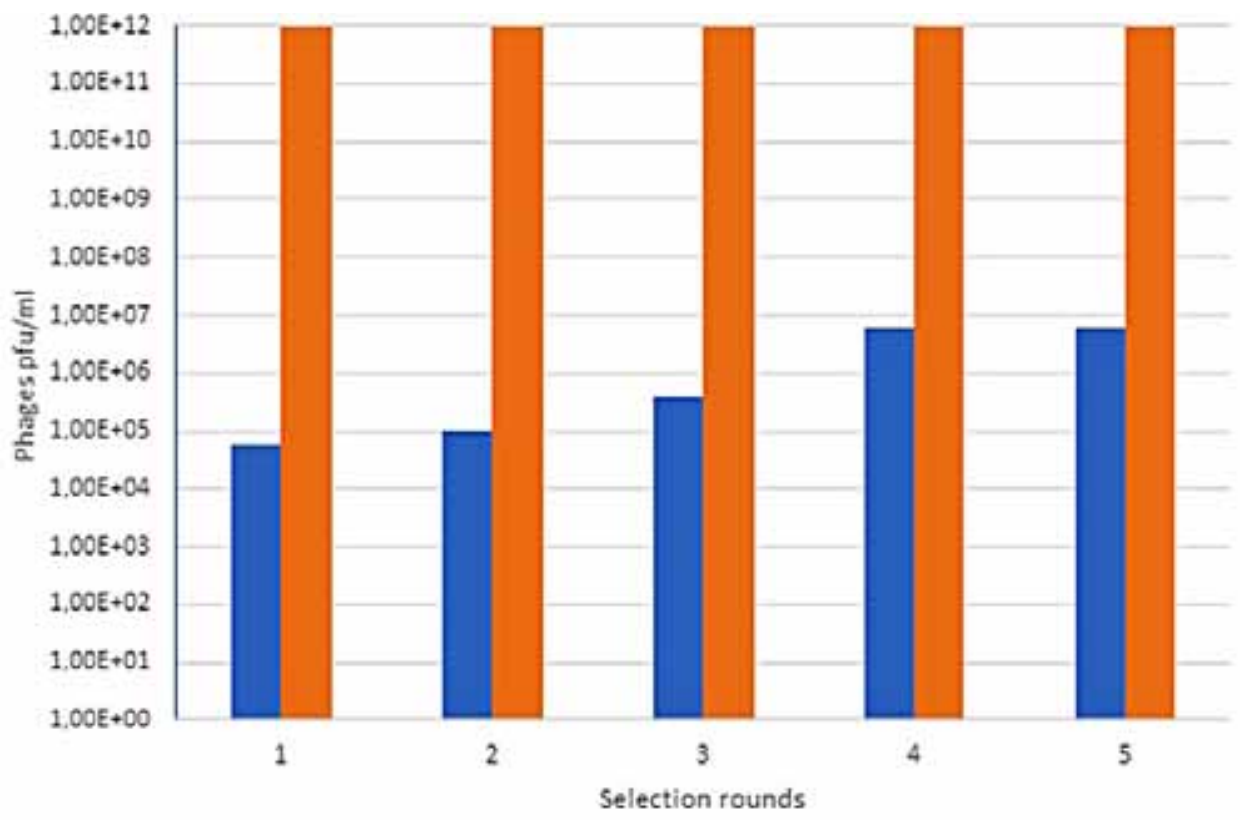

Fig. 1. Number of eluted phages. The blue columns show the number of eluted scFv-phages in each selection round. The orange columns indicate the number of input phages in each selection round.

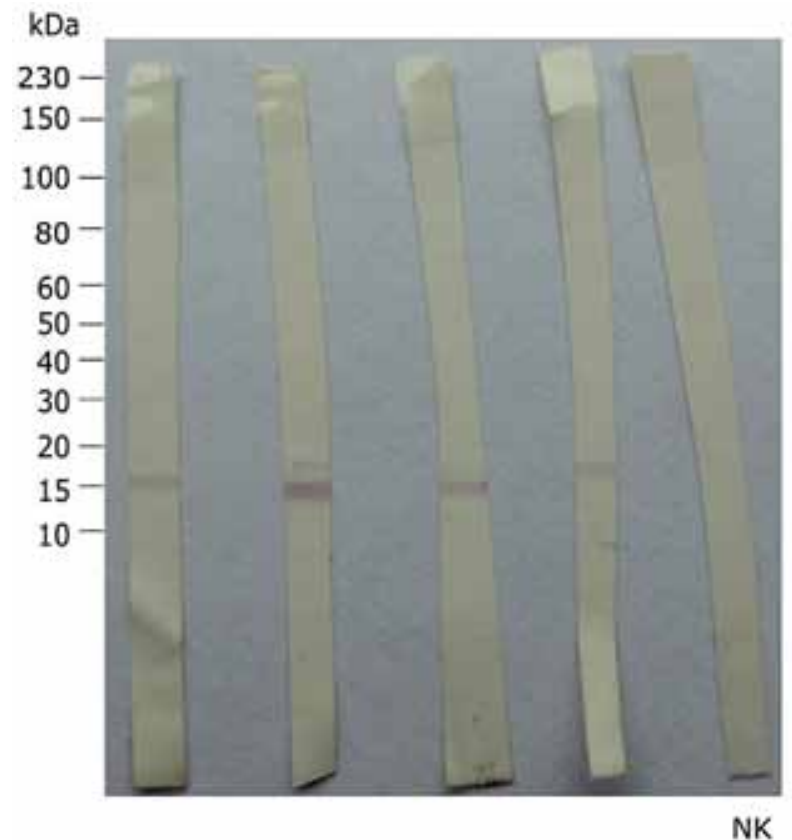

Fig. 2. Specific binding of $\mathrm{N}$ specific phage clones to purified recombinant $\mathrm{N}$ protein. Colour reaction with $15 \mathrm{kDa}$ protein band indicates a positive reaction (Lanes 1-4). ScFv antibody selected against irrelevant protein was used as negative control (NK). Molecular mass ladder is indicated on the left. 


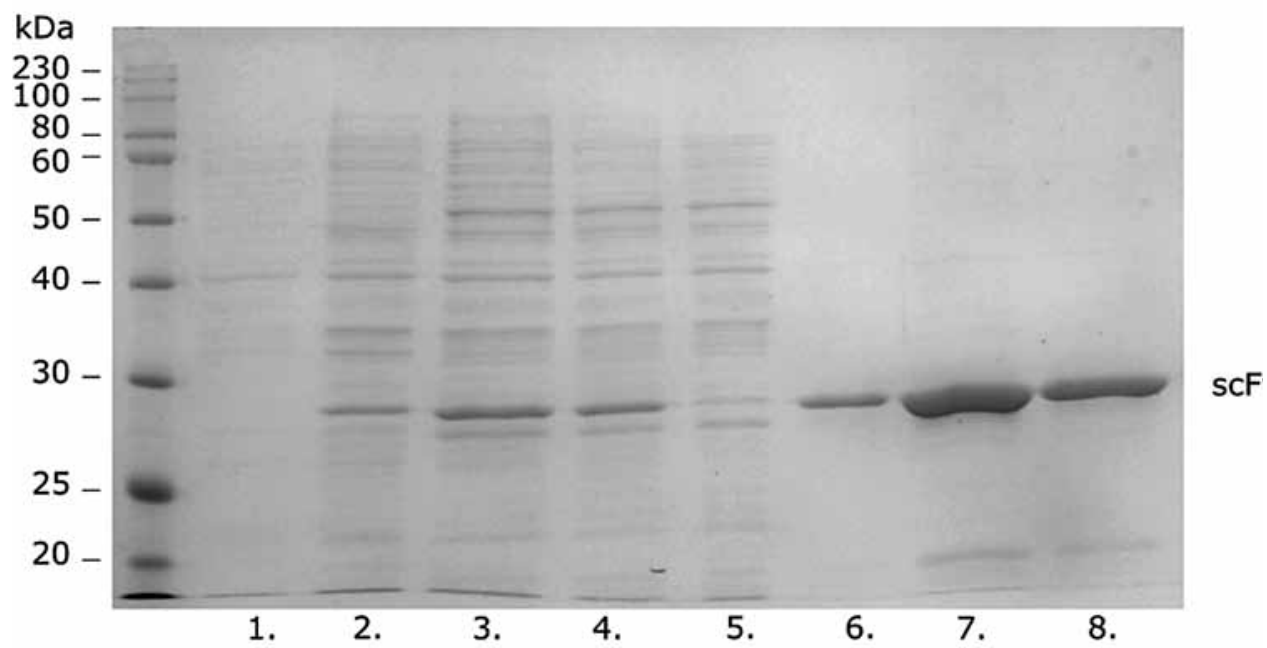

Fig. 3. Purification of the D5 scFv clone. Coomassie blue stained 12\% SDS-PAGE shows the level of purity of D5 $\mathrm{scFv}$ clone. Lane 1 - cell lysate before induction; lane 2 - cell lysate after induction; lane 3 - cell lysate following dialysis; lane 4 - cell lysate after incubation with $0.1 \mathrm{M}$ DTT and benzonase; lane 5 - cell lysate after incubation with agarose beads; lanes 6 to 8 - fractions of purified D5 scFv.

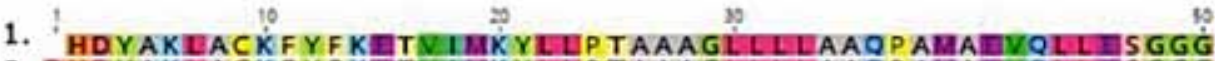
2. DHDYAKLACKFYFK TIIIKYLLPTAAAGLLLLAAQPABADVQLLDGGG

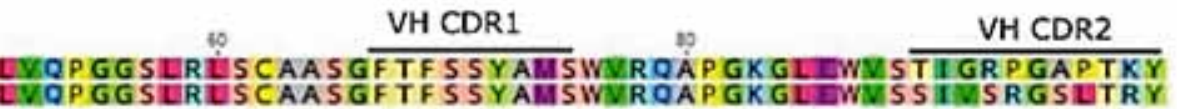

VH CDR2 110 $1: 9$

VH CDR3 ADSNKGRFTIISRDNSKNTLYLOIANSIRAIDTAVYYCAKLGRRFDYWGOGT ADSWKGRF TIISRDNS KNTEYLOLNS LRAEDTAVYYCAKF SS SF DYWGOGT

16. Linker 190 190 VL CDR1 EVTMSSGGGGSGGGGSGGGGSTDIOHTOSP SSUSASNGDRVTITCRASOS LVTISSGGGGSGGGGSGGGGSTDIOITOSPSSISASNGDRITIITCRASOS

\section{VL CDR1 20 VL CDR2 210 IIS SYLNWYQQKP GKAPKLLIYRASHLQSGUP SRF SGSGSGTDF TITIIS SL}

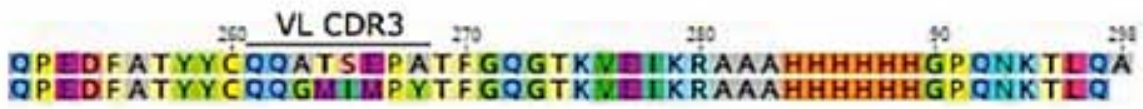

Fig. 4. Comparison of amino acid sequences of two identified clones: D5 (1) and B4 (2). CD regions of VH and VL chains are underlined. 


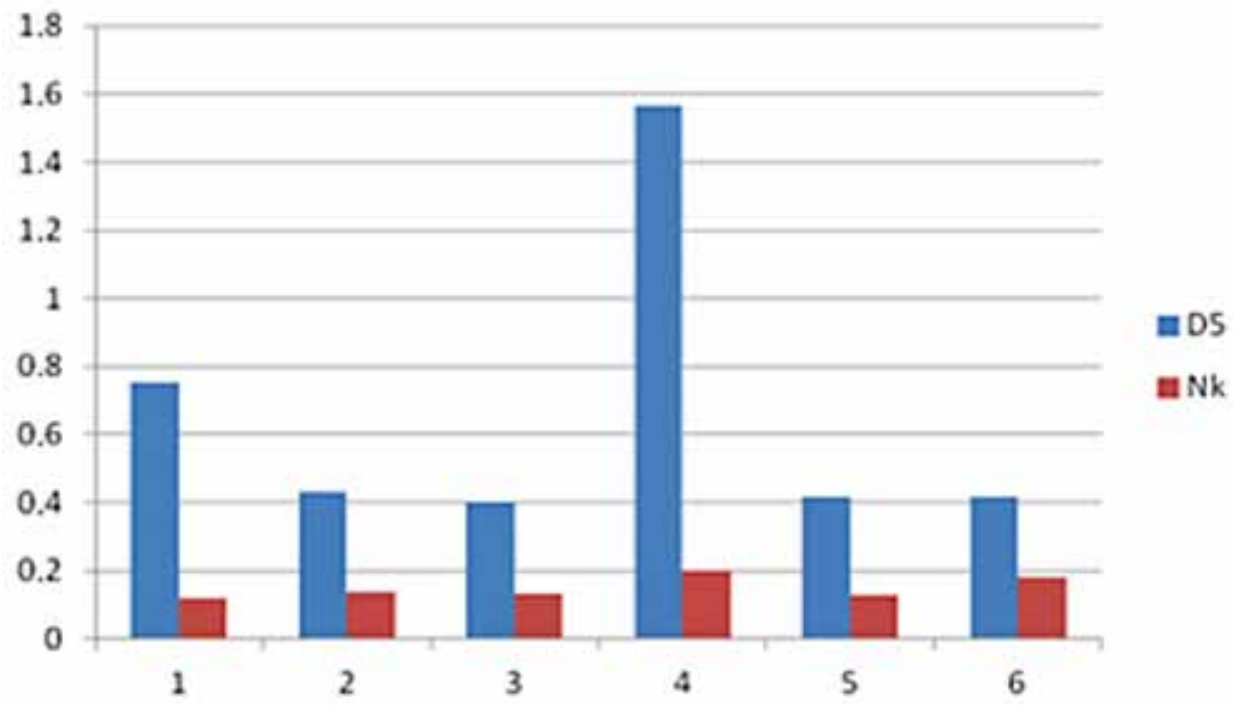

Fig. 5. Reactivity of D5 scFv with $\mathrm{N}$ protein fragments. Identification of protein fragments is shown in Table 1. Irrelevant $\mathrm{scFv}$ antibody was used as negative control.

\section{Competetive ELISA}

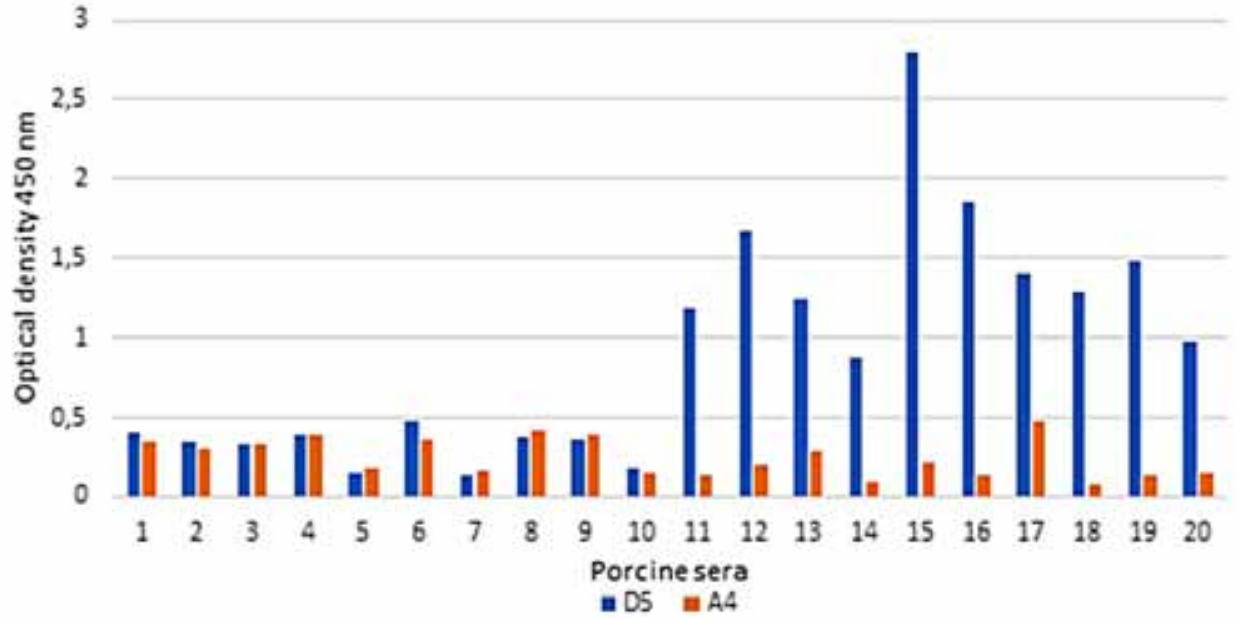

Fig. 6. Competitive N-protein ELISA test. PRRS positive (samples 1-10) and PRRS negative (samples 11-20) porcine sera were tested using D5 scFv clone (blue columns) and irrelevant scFv clone (orange columns). 